\title{
Diffusion as the main process for mass transport in very low water content argillites: 2. Fluid flow and mass transport modeling
}

\author{
Delphine Patriarche, ${ }^{1,2}$ Emmanuel Ledoux, ${ }^{1}$ Jean-Luc Michelot, ${ }^{3}$ \\ Régine Simon-Coinçon, ${ }^{1}$ and Sébastien Savoye ${ }^{4}$
}

Received 16 August 2003; revised 4 November 2003; accepted 13 November 2003; published 21 January 2004.

[1] On the basis of chloride concentrations of pore water in the Tournemire massif (part 1), a conceptual model for mass transport in argillites by diffusion is proposed. From this conceptual model and current knowledge of the geological history of the massif, one-dimensional numerical simulations are formulated for chloride transport in Tournemire massif over the past $53 \mathrm{Ma}$. Good agreement between experimental data and calculated values for both diffusion coefficients and concentrations of chloride confirms that diffusion is the main process for mass transport in the massif. This model is also tested using deuterium contents of pore water, applying variable concentrations to meteoric water (circulating in system boundary layers) based on the thermal dependency of its isotopic composition. These simulations reveal the likely important role of lithologic heterogeneities, such as fractures, in the horizontal distribution of tracer concentrations. INDEX TERMS: 5134 Physical Properties of Rocks: Thermal properties; 1020 Geochemistry: Composition of the crust; 1040 Geochemistry: Isotopic composition/chemistry; 1832 Hydrology: Groundwater transport; 1833 Hydrology: Hydroclimatology; KEYWORDS: interstitial water, porosity, deuterium, chloride, diffusion coefficients, transport modeling

Citation: Patriarche, D., E. Ledoux, J.-L. Michelot, R. Simon-Coinçon, and S. Savoye (2004), Diffusion as the main process for mass transport in very low water content argillites: 2. Fluid flow and mass transport modeling, Water Resour. Res., 40, W01517, doi:10.1029/2003WR002700.

\section{Introduction}

[2] Over the last two decades, hydrogeological studies related to evaluating the safety of radioactive waste storages, have primarily focused on very low hydraulic conductivity media. Understanding how elemental migration occurs with time in such media is crucial for qualitatively and quantitatively estimating the consequences of possible leakage of radioelements. To do so, numerical models of geological systems have become quite common for simulating fluid flow, mass transport, and geochemistry.

[3] Because of very low fluid flow velocities in lowconductivity media, time constraints generally preclude artificial tracers for evaluating mass transport. It is therefore necessary to consider the utility of natural tracers already present in the system, which may help to characterize water flow and solute transport. While Desaulniers et al. [1981] and Harrington et al. [2001] combined several tracers for gathering information on mass transport, Falck et al. [1990] and Stone [1992] focused on chloride concentrations and

\footnotetext{
${ }^{1}$ Ecole Nationale Supérieure des Mines de Paris, UMR 7619, Fontainebleau, France.

${ }^{2}$ Now at Department of Geological Sciences, University of Michigan, Ann Arbor, Michigan, USA.

${ }^{3}$ OrsayTerre, FRE 2566 CNRS, Faculté des Sciences, Université de Paris-Sud, Orsay, France.

${ }^{4}$ Institut de Radioprotection et de Sûreté Nucléaire, Fontenay-aux-Roses, France.

Copyright 2004 by the American Geophysical Union. 0043-1397/04/2003WR002700
}

isotopic contents of pore water. Most of these site studies have investigated Quaternary geologic units.

[4] Recently, more studies using natural tracers to examine the history of mass transport in older layers have appeared in the literature. Because of its well-known conservative behavior, several authors [Degueldre et al., 2003; Lippmann et al., 1998; Rübel, 2000; Rübel et al., 2002; Waber, 2001] have studied chloride contents in pore water of the Lower and Middle Jurassic Benken and Mont Terri sites in Switzerland. On the basis of profiles of chloride and other tracers throughout these geological sequences, and despite relatively sparse data, they found that the shape of tracer profiles describes what can be interpreted as a predominantly diffusion process through the 250-meter thick aquitards of these two sites.

[5] Another important aspect of issues related to transport in "old" formations is the nature of variations of boundary conditions over long time periods. While Konikow and Bredehoeft [1992] and de Marsily et al. [1992] for example, discuss about the inherent difficulty in validating hydrogeological models, most of studies use short time simulations [Falck et al., 1990] and/or sets of boundary conditions as constant parameters over significant spans of geologic time [Desaulniers et al., 1981; Hendry and Schwartz, 1988; Hendry and Wassenar, 1999]. One of the main challenges to mass transport modeling is to obtain both hydrogeological and geochemical boundary conditions of the system that are valid over long time intervals; above all this requires that knowledge of the geological history of the site be as accurate as possible. 


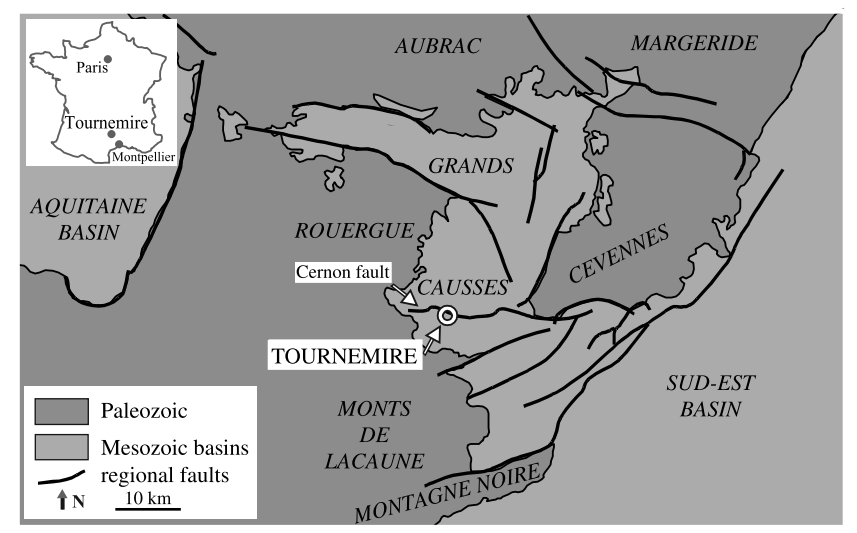

Figure 1. Regional map showing Mesozoic basins, the Paleozoic shelf, and the Cernon fault and Tournemire locations, after Simon-Coinçon and Schmitt [1999].

[6] In part 1 [Patriarche et al., 2004] of this study, we presented a technique for obtaining valid data on chloride content of interstitial water in Tournemire argillites, and for estimating chloride diffusion coefficients in this media. The chloride concentration profile, obtained from more than 100 data using this protocol, suggests that diffusion could be the main process for long-term mass transport in argillites over the geologic history of the sequence.

[7] Here, in order to check this hypothesis, we compare data profiles of chloride (part 1) and deuterium content of pore water (see auxiliary data tables) and calculated profiles obtained by numerical modeling. ${ }^{1}$ In order to do so, we reconstruct the geological history of the Tournemire massif using geological and environmental information to assess paleohydrogeological settings and major climate changes. This information provides the framework for processes of mass transport in the Tournemire argillites. In addition, application of paleotemperature data allows for a determination of deuterium contents in precipitation over time to apply at the system boundaries of the model. We describe a conceptual model for mass transport in the time frame where this process has been occurring. After describing modeling tools and parameters used in this study, we present a calibration of the numerical model of chloride transport over the past 53 million years. We also present data on interstitial water deuterium content, and the use of the deuterium profile for evaluating the validity of two scenarios of deuterium content in precipitation. Finally, the nature and importance of information about mass transport in the Tournemire argillites derived from the comparison between modeling of deuterium and chloride simulations are discussed.

\section{Geological History of the Tournemire Site and Hydrogeological History for a Conceptual Model of Mass Transport Through the Massif}

[8] The Tournemire site is located in southern France (about $120 \mathrm{~km}$ north of Montpellier), in the western border of the Causses Basin (Figure 1), a Mesozoic sedimentary

${ }^{1}$ Auxiliary material is available at $\mathrm{ftp} / / \mathrm{ftp}$.agu.org/apend/wr/ 2003WR002700 basin surrounded by the mounts of Lacaune, Margeride, Larzac, Montagne Noire, and Cévennes. As described in details in part 1 of this study, the Tournemire site is characterized by an alternation of subhorizontal calcareous and marl/argillites layers of Lower and Middle Jurassic (Figure 2). The calcareous layers are very active karstic aquifers. The deeper aquifer is located in Lower Jurassic units (Hettangian and Carixian) and the upper aquifer in Middle Jurassic layers (mostly the Aalenian). Lower Jurassic Toarcian and Domerian marls and argillites are located between these two aquifers. Relatively to these layers, Trias units constitute the impermeable substratum of the area of interest. The structural and stratigraphic features of the site delimit the current hydrogeological system wherein hydraulic heads of the upper and deeper aquifers suggest a downward flow through the argillites. However, the low hydraulic conductivities of the argillites determined by Boisson et al. [1998, 2001], and the shape of the vertical profile of interstitial water chloride content, suggest that fluid flow rates in the Toarcian and Domerian units are very low and consequently, diffusion could be the main process for mass transport in the argillites.

\subsection{Geological Settings Over Time}

[9] In order to assess the various processes involved in mass transport, the geological history of the Tournemire massif as established by Simon-Coinçon and Schmitt [1999] may be summarized as follows.

[10] 1. From 296 to $248 \mathrm{Myr}$ ago the Tournemire massif is part of the Grands Causses Basin, itself belonging to the Tethys. The pre-Jurassic evolution of the region (Figures 3a, $3 \mathrm{~b}$ and $3 \mathrm{c}$ ) includes developments of the Grands Causses Basin; the basin contains Upper Jurassic sediments lying on the Stephano-Permian basement.

[11] 2. From 248 to $200 \mathrm{Myr}$ ago, filling of the Grands Causses Basin began in the Trias and Sinemurian epicontinental transgressive episodes. The sea was shallow, and was occasionally characterized by lagoon conditions.

[12] 3. From 200 to $188 \mathrm{Myr}$ ago, during the Domerian, the Grands Causses Basin became deeper and the sedimentation more clayey. The basin was more or less connected to the opened sea, and underwent rapid subsidence during the accumulation of Domerian and Carixian sediments. Water over these sediments was probably shallow. Later, because the Tournemire site was located in the center of the basin, a significant thickness of Toarcian sediments accumulated at this area.

[13] 4. From 188 to $169 \mathrm{Myr}$ ago the Aalenian age marked a return of calcareous sedimentation, which continued in to the Bathonian; instability in the basin center gave rise to a shelf, which experienced alternations of immersion and uplift.

[14] 5. From 169 to $144 \mathrm{Myr}$ ago, Callovian continued in the central part of the basin but is inseparable of Bathonian units. Upper Jurassic sediments are still present over a large part of the Causses, but are not present on top of Bathonian units at Tournemire, an absence that implies that sedimentation had either stopped in this area, or that Upper Jurassic units were subsequently removed by erosion. Similarly, Lower Cretaceous deposition may also have occurred at the Tournemire location.

[15] 6. From 144 to $36 \mathrm{Myr}$ ago, many uncertainties remain about the evolution of the Grands Causses Basin 


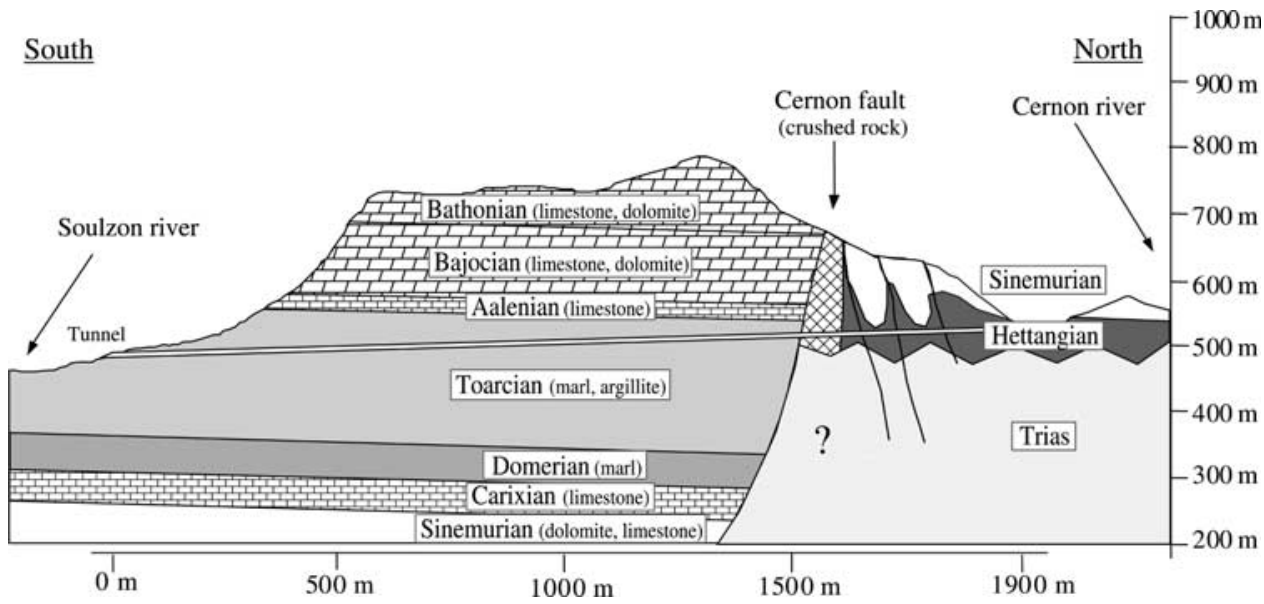

Figure 2. Vertical cross section of the Tournemire massif showing the Trias and Jurassic successions interrupted by the Cernon fault; investigation of the Tournemire massif was performed by drilling boreholes upward and downward from the tunnel crossing the Upper Toarcian (provided by J. Cabrera).

from the end of the Jurassic era to the beginning of Tertiary. Despite dolomitization, the oldest identifiable deposits above Jurassic units are dated as being Upper Cretaceous. From east to west, they directly overlie Malm, Callovo-Oxfordian, Bathono-Callovian and Bajocian units; this discordance reflects simultaneous erosion (before the Upper Cretaceous transgression) and tilting of the Basin [Bruxelles, 2001]. While it is possible that a short transgression occurred during the Paleocene, recognized Upper Cretaceous and Paleocene deposits seem to be vestiges of relatively short sedimentation events. Simon-Coinçon and Schmitt [1999] conclude that significant uplift of the Tournemire massif could have occurred at the end of the Portlandian or soon after, during Cretaceous. During the Middle Eocene to the LutetianBartonian transition, numerous drain networks (essentially karstic) developed across the region. The evolution of the Grands Causses Basin was then marked by a major tectonic event, the Pyrenean orogenesis, which occurred from 53 to $33 \mathrm{Myr}$ ago, with a paroxysm about $42 \mathrm{Myr}$ ago.

[16] 7. From 36 to 5.1 Myr ago a new phase of extension has followed the Oligocene and is responsible for relative land subsidence of the Grands Causses Basin compared to the surrounding mountains. Erosion occurred slowly during this period, and the beginning of the karstification [Ambert and Ambert, 1995] took place during the Burdigalian (-20 Ma). During Upper Neogene (from 15 to $13 \mathrm{Myr}$ ago), lowering of sea level resulted in an initial episode of intensive erosion, which contributed to create valleys and to lower water levels [Ambert and Ambert, 1995].

[17] 8. From 5.1 to $3 \mathrm{Myr}$ ago the region experienced intense volcanic activity. Reopening of the Gibraltar Strait after the Messinian event (from 5.3 to 3.7 Myr ago) [Blanc, 1997] generated a temporary heightening of water levels, which thus limited the erosion.

[18] 9. From $3 \mathrm{Myr}$ ago to today, tectonic uplift of the Massif Central caused intense deepening of preexisting valleys by relatively lowering water levels [Derruau, 1973].

\subsection{Hydrogeological History}

[19] This geological history described above shows that the paleohydrogeological features of the massif are still unclear, but the main trends are useful for inferring realistic hydrogeological conditions over time. These hypotheses can be summarized as follows (Figure 4):

\subsubsection{Hypothesis on the History of Fluid Flow}

[20] Karstification could have begun in the study area at the end of the Cretaceous and/or the very beginning of Tertiary, but its impact still remains difficult to quantify. Despite tectonic events (mainly Pyrenean orogenesis) that created fractures, we assume that the Dogger and Lias units remained in a near hydrostatic state until the Burdigalian episode, when the uplift had occurred and the karstification began. Fracturing could have allowed for local circulations, but hydraulic heads between the two aquifers surrounding the argillites could have remained equal over most of this time. This situation probably changed during initial deepening of valleys from -15 to $-13 \mathrm{Ma}$; at this time, the hydraulic head in the lower aquifer could have become higher than that in the upper aquifer due to the presence of low hydraulic conductivity layers in between and thus could have generated upward flow. Because of difficulty in arriving at a realistic assessment of hydraulic heads during this period, we do not include this fluid flow event in our modeling. We assume that hydraulic heads of both aquifers were initially equal, and then that of the lower aquifer uniformly decreased during the last $3 \mathrm{Ma}$, reaching its present-day value.

\subsubsection{Hypothesis on the History of Mass Transport}

[21] We know that the major fractures in the Tournemire massif were created or reactivated across the entire massif during Pyrenean orogenesis. These faults could have been paths for local water circulations. In particular, we assume that fresh water from precipitation could have accessed the Aalenian/Upper Toarcian boundary. Although this entry could have been restricted to areas in the vicinity of faults separating major blocks, we assume for modeling the contact between fresh water and seawater at the boundaries of the clayey formation began 53 Myr ago.

[22] The geological history of the massif suggests that the fracturing ability of the argillites was acquired quite early (fractures dated to $\sim 42 \mathrm{Ma}$ ). Loss of water and decrease of porosity was likely rapid, and very low hydraulic conductivities were acquired early in the history of the massif. This indicates that fluid flow could have 

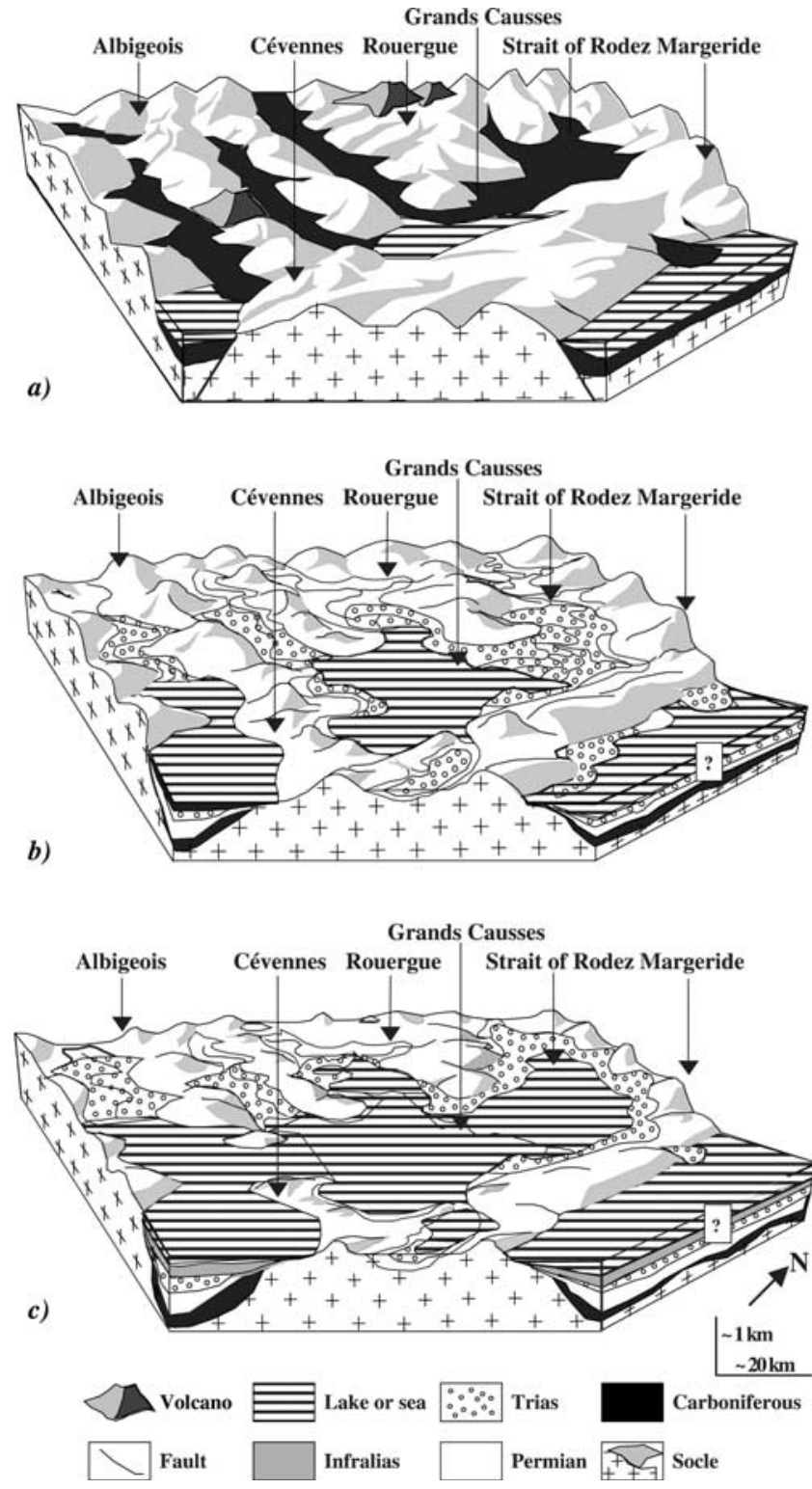

Figure 3. Landscape evolution of the Grands Causses Basin, from Simon-Coinçon and Schmitt [1999]; (a) Carboniferous deposits (-286 Ma), (b) Permian (from -286 to $-248 \mathrm{Ma}$ ) and Trias (from -248 to $-219 \mathrm{Ma}$ ) deposits, and (c) Rhaetian and Hettangian deposits (from -219 to $-206 \mathrm{Ma})$.

been a minor process for most of the history of these rocks, leaving diffusion as the main process for mass transport in these argillites.

\subsection{Conceptual Model for Mass Transport Through the Argillites}

[23] The conceptual model for mass transport that we propose to test in the Tournemire argillites is based on the fact that both upper and lower horizontal units that bound the argillites are karstic aquifers where fresh water (from precipitation) is actively circulating. It is also based on the assumption that initial pore water in argillites was seawater trapped during deposition of the clayey layers (Figure 5, stage 1).
[24] When calcareous layers were karstified, the contrast in chemical and isotopic concentrations between the two kinds of water would result in diffusion (Figure 5, stage 2). Equilibration between the two fluids would proceed over time (Figure 5, stages 3 to 6) before reaching a final state with a uniform concentration corresponding to the chemical signature of the fresh water over the entire geological sequence (Figure 5, stage 7). This diffusion process of exchange between dissolved elements of these two reservoirs can only reach this ideal final state if the tracers under study do not exhibit variable concentrations with time in the aquifer at the boundaries of the argillites. This is not the case for deuterium in meteoric precipitation, which is particularly sensitive to ambient air temperature. If the concentration of some tracer is indeed varying over time, then the integrated effect of these variations could be recorded in the tracer profile in argillites.

[25] Diffusive transport is dependent of the media temperature and may be affected by competitive processes such as osmotic transport. Diffusion coefficients vary with temperature and can either enhance or reduce diffusive transport rates. Considering the effective uplift of the basin took place at the end of the Portlandian or even in the Cretaceous (section 2.1), the geodynamic model of the Tournemire site provided by D. Bruel (unpublished manuscript, 2000) shows that any dramatic burial or erosion of the massif occurred from $74 \mathrm{Ma}$ to today and consequently that, during this period of time, temperature within the massif remained relatively stable. Therefore change in ground temperature and its effect on diffusion coefficient over time are not considered in our modeling.

[26] Transport from the development of osmotic pressure [Hinch, 1980] can occur in low porosity shale that exhibits membrane properties [Neuzil, 2000]. However, as noted in part 1 of this study, argillites and marls in Tournemire are composed of less than $20 \%$ of clays such as illite or illite/ smectite that have membrane properties. It therefore seems that strong osmotic processes would not occur in Tournemire material. Moreover, hydraulic heads (Figure 6a), representative of water pore pressure, do not show any sign of past overpressure, which does not allow for assessing any development of strong osmotic pressure anomalies over the geological history of the Tournemire massif. Therefore osmotic transport is not taken into account in our modeling.

\section{Modeling Tools}

\subsection{Numerical Code}

[27] The numerical code used for evaluating the importance of diffusion process in mass transport in Tournemire argillites is the code METIS [Cordier and Goblet, 1999; Goblet, 1989]. METIS is a finite element code, using the bilinear isoparametric approximation for the variables and physical parameters, allowing for the replacement of the continuous problem by a discrete problem, and using the Galerkin approach to solve the integration of the fluid flow and mass transport equations in a porous media.

[28] For fluid flow in transient state, the solved equation of diffusivity is $\operatorname{div}(\overline{\bar{K}} \underset{g r a d}{\longrightarrow} h)=S_{s} \frac{\partial h}{\partial t}+q$ where $\overline{\bar{K}}$ is the tensor of the hydraulic conductivity $\left(\mathrm{m} \mathrm{s}^{-1}\right), h$ the hydraulic head $(\mathrm{m}), S_{S}$ the specific storage coefficient $\left(\mathrm{m}^{-1}\right)$, and $q$ a 


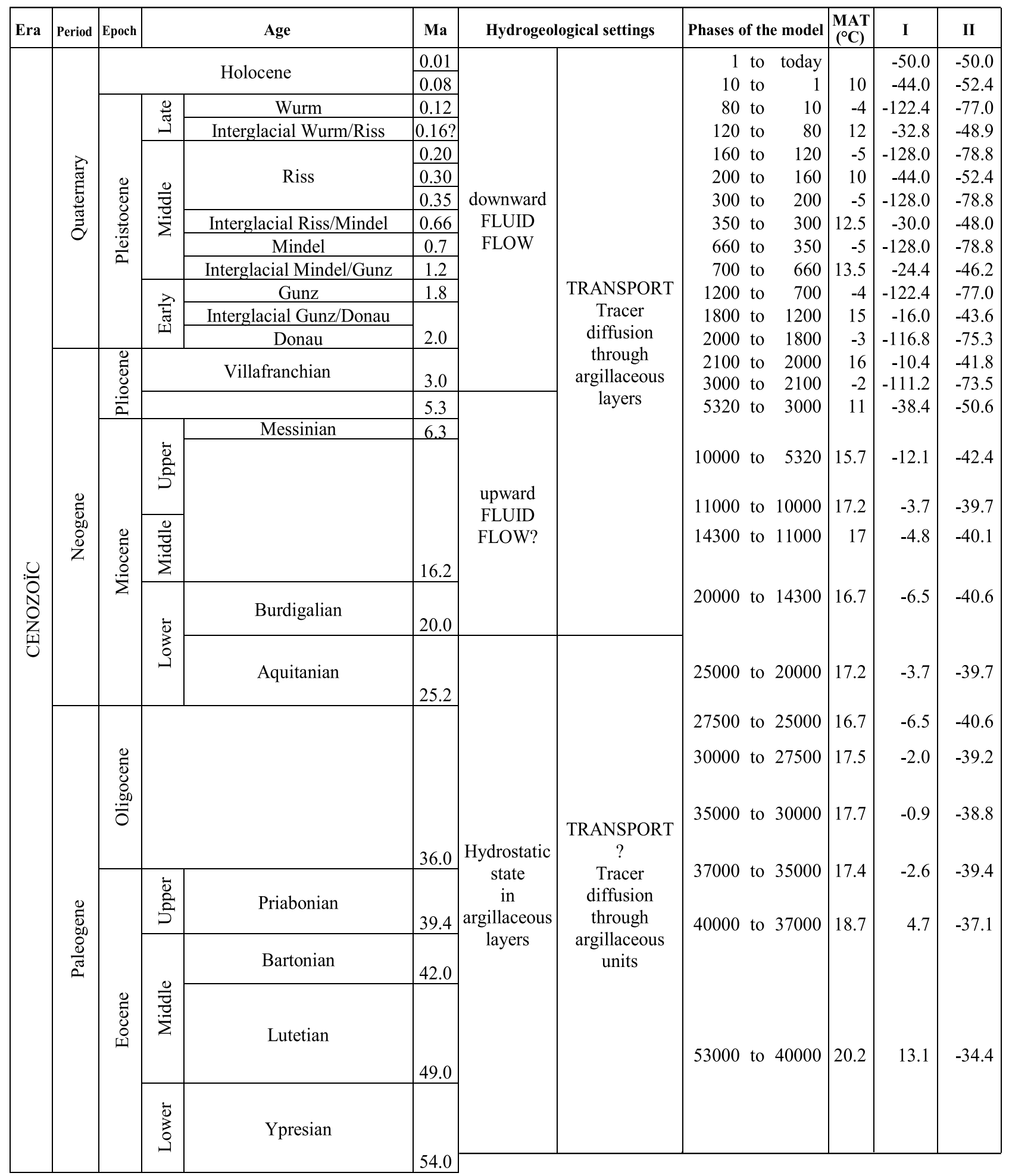

Figure 4. Geologic timescale, conceptual model for fluid, and mass transport in the Tournemire massif, time phases taken into account for the fluid flow and the deuterium transport calculations considering variable boundary conditions over time calculated considering the global and regional (see details in text) mean annual temperature (MAT) and the relations $\delta^{2} \mathrm{H}=5.6 \mathrm{MAT}-100$ (relation I) given by Dansgaard [1964] and $\delta^{2} \mathrm{H}=1.76 \mathrm{MAT}-70$ (relation II) from Craig [1961] and Huneau [2000]. 


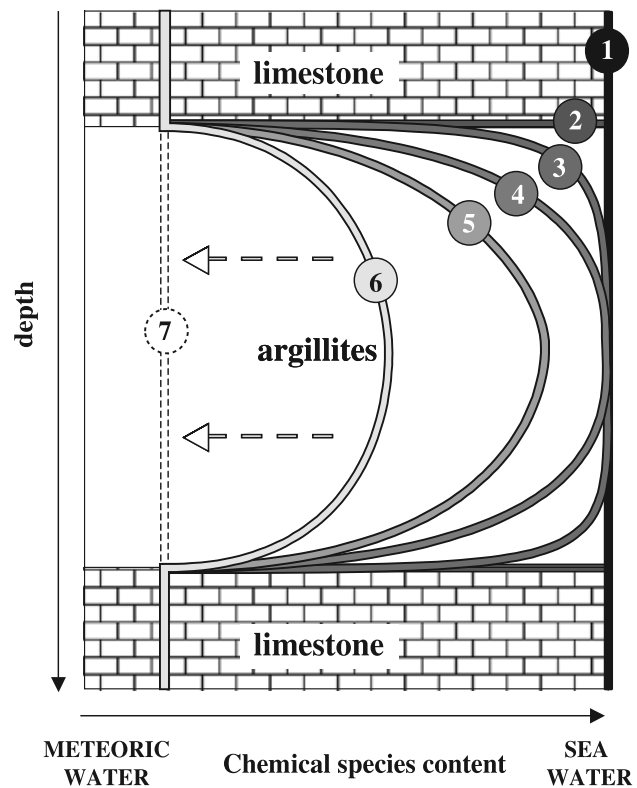

Figure 5. Conceptual model for mass transport by diffusion through an impermeable layer surrounded by karstic aquifers. Stage 1 is conditions of the system, before meteoric waters reached the aquifers. Stage 2 is initial conditions for diffusion when meteoric reached the aquifers. Stages 3 to 6 are progressive flattening of "bow" shape of a profile by diffusion.

source term $\left(\mathrm{s}^{-1}\right)$ associated to flow of added or withdrawn volume of fluid per unit of volume of porous media.

[29] Taking the three main processes of advection, molecular diffusion and dispersion into account, the equa- tion for mass transport solved by METIS is: $\operatorname{div}((\overline{\bar{D}}+$ $\left.\left.\omega_{d} \overline{\overline{D_{p}}}\right) \overrightarrow{\operatorname{grad}} C-C \vec{U}\right)=\omega_{e} \frac{\partial C}{\partial t}$ where $\vec{U}$ is the Darcy velocity $\left(\underline{\mathrm{m} \mathrm{s}}^{-1}\right), \overline{\bar{D}}$ is the tensor of the dispersion coefficient $\left(\mathrm{m}^{2} \mathrm{~s}^{-1}\right), \overline{D_{p}}$ is the tensor of the pore diffusion coefficient $\left(\mathrm{m}^{2} \mathrm{~s}^{-1}\right)$ of a chemical species in the porous media, $\omega_{d}$ is the diffusion porosity of the chemical species, $\omega_{e}$ is the porosity where advection and dispersion occur and $C$ the concentration of the species in water. Despite that $\omega_{d}$ and $\omega_{e}$ may differ, METIS consider one unique value for both porosities.

[30] On the basis of current knowledge of geologic history and chemical and physical indicators, it appears that mass transport has been largely due to diffusion. Also, as noted earlier, we only have an approximate idea of hydrodynamic boundary conditions during the past $3 \mathrm{Ma}$, and no "reasonable" scenario can be propose for the previous periods. As a result, except for the past $3 \mathrm{Ma}$, the only process we consider is diffusion.

\subsection{Numerical Model}

\subsubsection{Application of the Modeling Tool to the Tournemire Massif}

[31] The lower and upper aquifers are partially included in our modeling. The top of the Carixian unit corresponds to the lower limit of impermeable layers (Domerian and Toarcian) and is represented at the lower boundary as a unit of $1 \mathrm{~m}$ in thickness, playing the role of a perfect mixer. Aalenian units constitute the lower part of upper aquifer; while overlying Bathonian and Bajocian units once were part of this aquifer, at present, only the Aalenian is an aquifer, and is represented in the model as a $17 \mathrm{~m}$ thick unit that corresponds to the present phreatic zone. Thicknesses of the Domerian and Toarcian are $58 \mathrm{~m}$ and $202 \mathrm{~m}$, respectively. In order to account for mineralogical dispar-

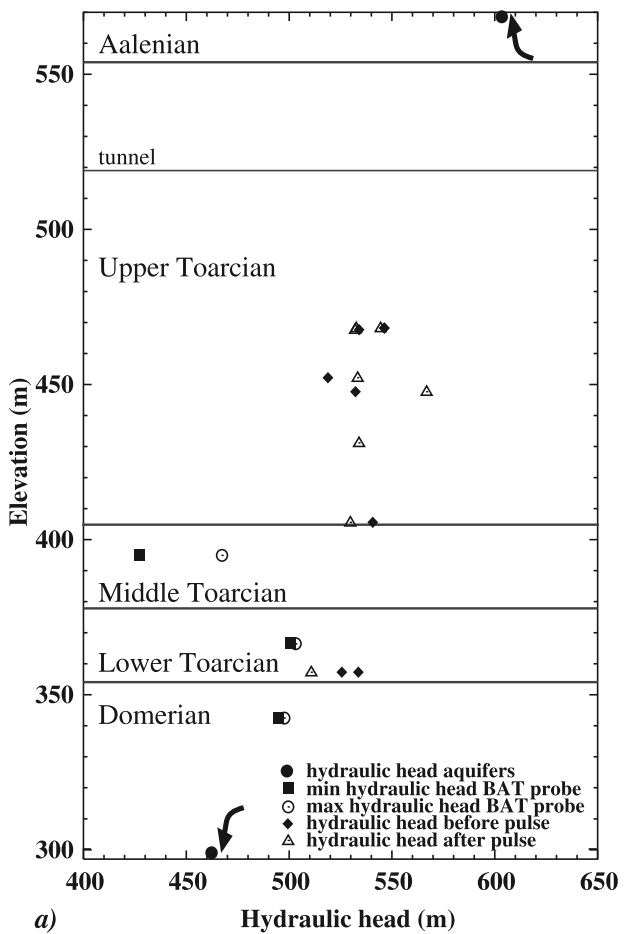

Figure 6. (a) Hydraulic head and (b) hydraulic conductivities chosen for modeling. Data are from Boisson et al. [2001]. 


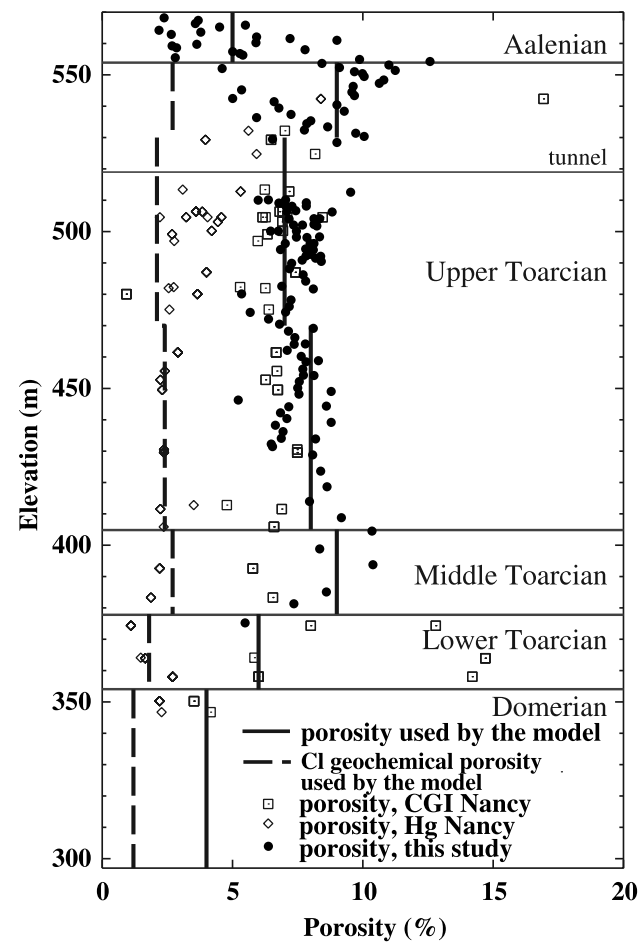

Figure 7. Porosities used in the modeling. Dashed line is the geochemical porosity for chloride (only in Toarcian and Domerian); solid line is the total porosity (for deuterium simulations in the whole sequence and for chloride simulations in Aalenian).

ities in Toarcian units, three sublayers were distinguished; a lower $(23 \mathrm{~m})$, a middle $(27 \mathrm{~m})$ and an upper $(152 \mathrm{~m})$.

[32] The simulations presented in this study have been performed in one dimension. The mesh is constituted by a column of 273 elements and by 548 nodes. The elements are quadrilaterals widths of $5 \mathrm{~m}$ and heights of $1 \mathrm{~m}$.

[33] One-dimensional simulations are performed assuming that units are lithologically homogeneous over each stratigraphic level. Moreover, data on chemical composition of interstitial water from several boreholes are combined into one synthetic profile. In order to respect the original lithostratigraphic level of each sample, a corrected elevation $z_{c}$ was calculated (for each sample location) taking into account the slope of the layers (from 3.9 to $7.4 \%$ ) and choosing boreholes TN1 and TN3 as a reference [Patriarche, 2001].

\subsubsection{Parameters for Argillite Properties}

\subsubsection{Hydraulic Conductivities}

[34] Present-day hydrogeological conditions were determined using hydraulic head measurements and assessment of hydraulic conductivities. The near linear distribution of measured heads with depth indicates no current overpressure in impermeable layers (Figure 6a); the hydraulic head of the upper aquifer $\left(602 \mathrm{~m}\right.$ at an elevation of $\left.588 \mathrm{~m}-z_{c} 574 \mathrm{~m}\right)$ is higher than that of the deeper one (463 $\mathrm{m}$ at the elevation of $296 \mathrm{~m}-z_{c} 283 \mathrm{~m}$ ). Hydraulic heads at intermediate depths seem to be regularly distributed, except for two somewhat anomalous measurements in the Middle Toarcian.

[35] Hydraulic conductivities were assessed using both laboratory and in situ experiments (results from Boisson et al. [2001]) (Figure 6b). Laboratory experiments (using permeation through argillite samples) yielded very low hydraulic conductivities $\left(10^{-14} \mathrm{~m}^{2} \mathrm{~s}^{-1}\right.$ and lower) for the matrix at a centimeter to decimeter scale, and were obtained assuming that Darcy's law was valid. In situ experiments were performed using pulse tests; they reflect the average hydraulic conductivity of media at a meter to decameter scale. At this scale, and due to mechanical stress, relative amounts of fluid flow through fault networks increase, giving generally higher hydraulic conductivities (from $10^{-13}$ to $10^{-11} \mathrm{~m}^{2} \mathrm{~s}^{-1}$ ).

[36] These hydraulic properties were used for fluid flow coupled to mass transport modeling for the last $3 \mathrm{Ma}$ of Tournemire history, during which time advection is assumed to have played a role. Very low fluid flow velocities (induced by these very low hydraulic conductivities) will certainly have a small effect on kinematic dispersion. Therefore kinematic dispersion is neglected and intrinsic dispersion coefficients are chosen equal to 0 .

\subsubsection{Diffusion Coefficients}

[37] As mentioned earlier, diffusion could have occurred over the past $53 \mathrm{Ma}$. This long history means that parameters controlling diffusion (concentration gradients and diffusion coefficients) are very important, and have to be well assessed. Concentrations and boundary conditions for chloride and deuterium are discussed in part 1 , sections 4 and 5, respectively. Pore diffusion coefficients for chloride were obtained from diffusion experiments. They were determined according to $D_{x}=2 D_{z}$ in order to take into account the 1:2 argillite anisotropy (part 1). Simulations are conducted in one dimension; vertical profiles of calculated and experimental diffusion coefficients represent the value $D_{z}$ equal to $D_{x} / 2$, where $z$ represents the elevation in an orthogonal Cartesian set.

[38] Diffusion coefficients used for modeling deuterium transport are experimental data obtained for tritium diffusion through Tournemire argillites samples. Beaudoing et al. [1994, 1996] monitored "through-diffusion" experiments for synthetic water marked with tritium (HTO); they measured tritium content of water after its diffusion/permeation through argillite samples. Knowing the entering and exiting fluxes, they calculated effective diffusion coefficients of tritiated water. Wang et al. [1953] gave $2.34 \times 10^{-9}$ and $2.44 \times 10^{-9} \mathrm{~m}^{2} \mathrm{~s}^{-1}$ for HDO and HTO diffusion coefficients respectively, at $15^{\circ} \mathrm{C}$ in free pure water. The difference between these two values is very low $\left(10^{-10} \mathrm{~m}^{2} \mathrm{~s}^{-1}\right)$ meaning that HTO diffusion coefficients may be used for HDO. In this study, deuterium (HDO) effective diffusion coefficients are chosen equal to the HTO values given by Beaudoing et al. [1994, 1996] (see auxiliary data tables).

\subsubsection{Total and Geochemical Porosities}

[39] Previous studies of the Tournemire site have yielded porosity values from throughout the sequence, calculated knowing wet and dry densities, and measured using mercury porosimetry [Boisson et al., 1998]. In this study, porosities were obtained using measurements of water content (part 1). Values were similar to those calculated previously using densities (Figure 7). Porosity values obtained by mercury injection were much lower due to the fact that mercury cannot access very small $(<0.003 \mu \mathrm{m})$ pore spaces [Moreau-Le Golvan, 1997].

[40] Total porosity used for fluid flow and deuterium transport modeling corresponds to total porosity $\left(\omega_{\theta}\right)$ calcu- 


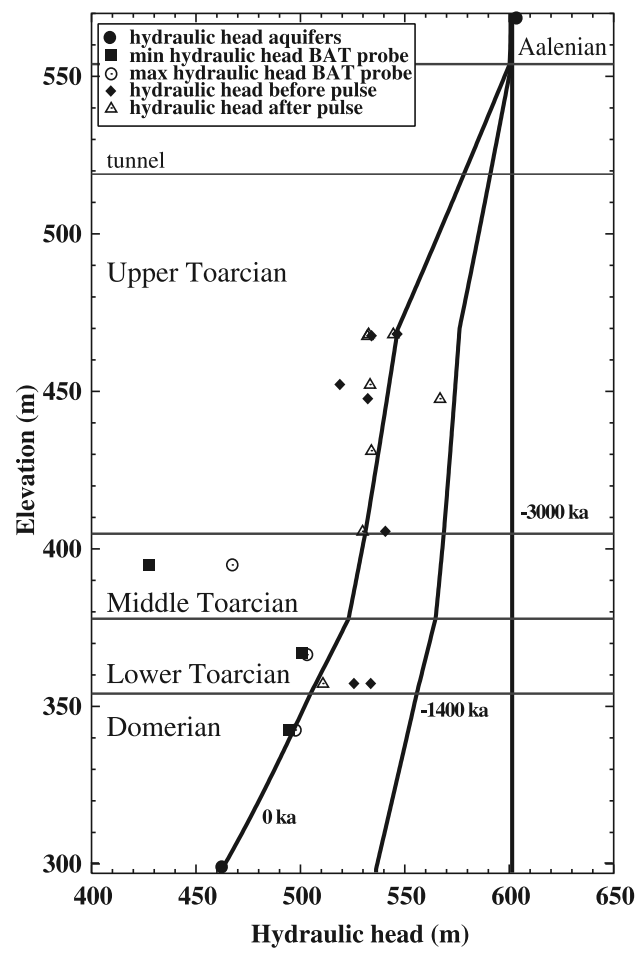

Figure 8. Hydraulic head evolution in the massif for fluid flow simulations: distribution at $-3 \mathrm{Ma},-1.4 \mathrm{Ma}$, and today.

lated from water content. Porosities used for modeling of chloride transport vary considering among different types of layers. For clayey Toarcian and Domerian units, porosity corresponds to geochemical porosity [Pearson, 1999] chosen equal to $\omega_{\text {geoch }}=0.3 \omega_{\theta}$ (part 1 , section 4 ). For the Aalenian layer, porosity is considered equal to total porosity $\left(\omega_{\theta}\right)$. Total porosity values used in simulations are $5 \%$ for the Aalenian, $9 \%, 7 \%$, and $8 \%$, for the upper, middle and lower parts of the Upper Toarcian, respectively, 9\% and $6 \%$ for the Middle and Lower Toarcian, respectively, and $4 \%$ for the Domerian (Figure 7).

\subsection{Implementation and Calibration of the Model}

[41] The diffusion coefficients used in transport modeling will be calibrated. To do so, a best fit for the calculated tracer concentration profile is obtained through trial and error by adjusting the tracer diffusion coefficient for each sublayer, and minimizing $S$, the sum of quadratic differences between measured $\left(C_{\text {meas }}\right)$ and calculated concentrations $\left(C_{m o d}\right)$ for each elevation in the profile where a sample is available. $S$ is given by $\sum_{1}^{i} \frac{1}{n_{i}} \sum_{1}^{n_{i}}\left(C_{\text {meas }}\right)^{-2}\left(C_{\text {meas }}-\right.$ $\left.C_{\bmod }\right)^{2}$ where $i$ is the layer number, $n_{i}$ is the number of data for layer $i$. The term $\left(C_{\text {meas }}\right)^{-2}$ is chosen for calculating the relative error between measured and calculated data, and it also allows for restituting small values of $C$.

[42] Because the purpose of this study is to show that diffusion can explain tracer concentration profiles, and considering that chloride and deuterium diffusion coefficients are known (part 1), evaluating the validity of this hypothesis is done by comparing computed diffusion coefficients and experimental data. As it is the case with any inverse modeling problem, one is faced with a lack of a unique solution for the calculation of diffusion coefficient distributions [de Marsily et al., 1992; Kitanidis, 1997; Konikow and Bredehoeft, 1992; Maloszewski and Zuber, 1993; McLaughlin and Townley, 1996; McLaughlin and Townley, 1997]. Nonetheless, in our case, the large amount of available experimental data brings a valuable constraint for a confident comparison between calibrated and experimental data.

[43] Calculations for deuterium simulations, where boundary conditions (deuterium concentrations) change over time, are performed in several time sequences, each starting with results from the previous sequence. As such, only the first sequence has predefined initial conditions.

\section{Chloride Simulations: A Calibration for the Hydrogeological Model}

\subsection{Data Acquisition}

[44] Because of the very low water content of argilites, measurement of chloride concentration of interstitial water was not possible using direct classical methods. Details of technical developments for this data acquisition, as well as data sets of Tournemire argillite chloride pore water contents and diffusion coefficients are given in part 1.

\subsection{Initial and Boundary Conditions for Chloride}

[45] Testing of the conceptual model presented on section 2.2 begins with an initial condition of seawater in the impermeable layers. The chloride content of seawater at the end of sedimentation (beginning of Cretaceous) is not well known due to the lack of seawater paleosalinity indicators. On the basis of the composite low latitude temperature curve given by Douglas and Woodruff [1981], Cretaceous temperatures were slightly warmer (to $7^{\circ} \mathrm{C}$ ) than at present. It suggests that Cretaceous climates were perhaps more favorable for evaporation, which could have lead to a higher concentration of solutes in seawater. However, because this presumption cannot be confirmed, Cretaceous seawater chloride content is assumed equal to present concentrations $(20 \times$ $10^{3} \mathrm{mg} \mathrm{L}^{-1}$ ); thus, in our model, chloride pore water concentration in argillites $53 \mathrm{Myr}$ ago is equal to this value.

[46] Chloride contents of meteoric precipitation largely depend on distance between the area of interest and the sea [Meybeck, 1984; Schoeller, 1961]. While the distance between Tournemire and the ocean changed during regression and transgression, at a continental scale it remained relatively short [Simon-Coinçon and Schmitt, 1999], except during Quaternary glacial periods. Because concentration in precipitation probably remained relatively constant, chloride concentration meteoric water present in Carixian and Aalenian aquifers is assumed equal to that in present-day precipitation at Tournemire $\left(5 \mathrm{mg} \mathrm{L}^{-1}\right)$. Because chloride content of rainwater is very low compared to that of initial seawater contained in argillite pores, assumptions about rainfall chloride contents have little impact on simulations.

\subsection{Simulations}

\subsubsection{Modeling With Assumption of Diffusion Over} 53 Ma and Fluid Flow Over the Last 3 Ma

[47] Mass transport simulations assume diffusion process over the first $50 \mathrm{Ma}$, and a coupled calculation of fluid flow and diffusional mass transport (excluding kinematic dispersion) over the last $3 \mathrm{Ma}$. Initial hydraulic heads of the upper and lower boundaries are initially fixed at a value of $602 \mathrm{~m}$ (which is the present value that we have arbitrarily 

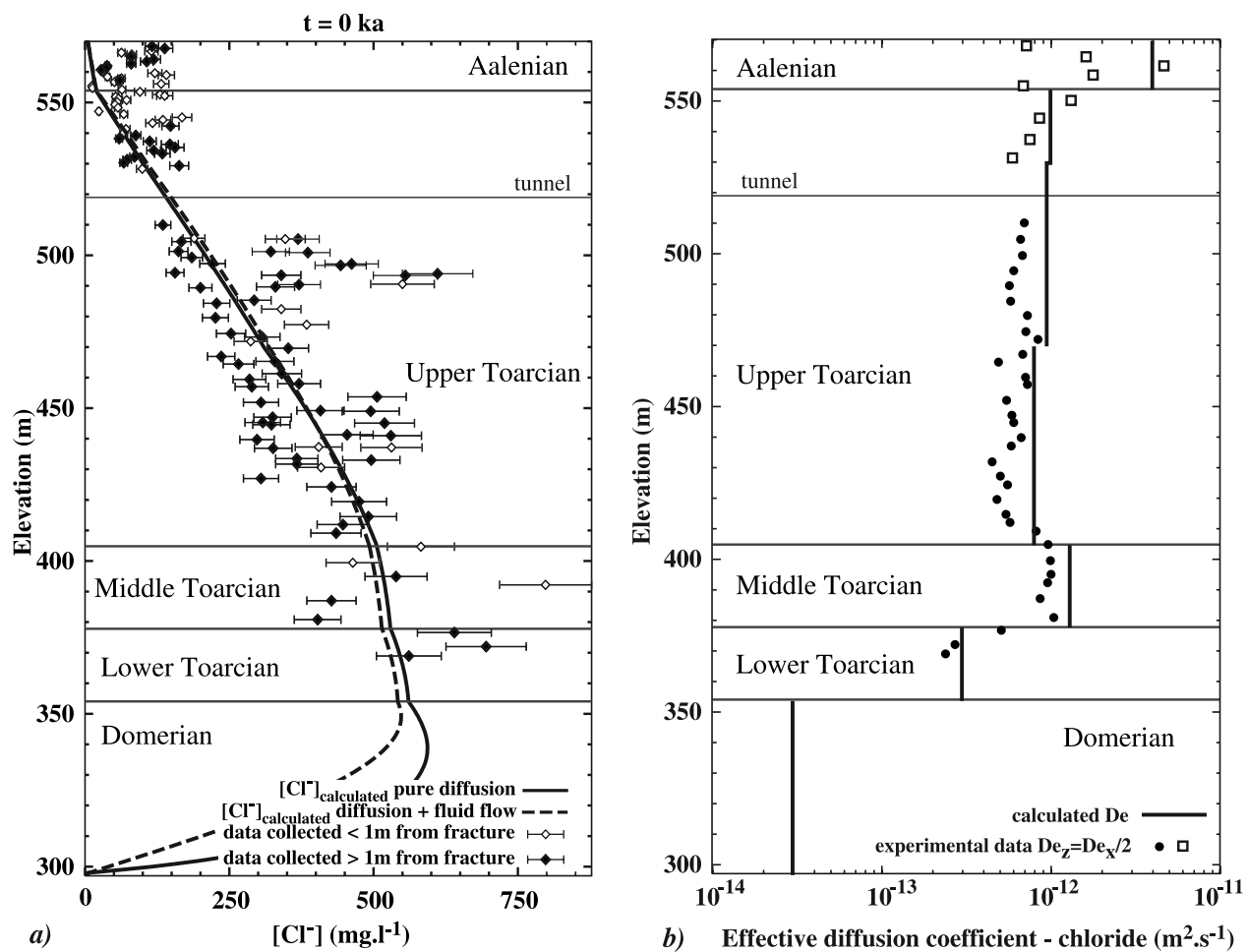

b) Effective diffusion coefficient - chloride $\left(\mathrm{m}^{2} . \mathrm{s}^{-1}\right)$

Figure 9. (a) Vertical profiles of experimental and calculated chloride concentrations at the present time for simulations of pure diffusion over the past $53 \mathrm{Ma}$ (solid line) and diffusion over $53 \mathrm{Ma}$ with fluid flow over the last $3 \mathrm{Ma}$ (dashed line) and (b) vertical profile of experimental $\left(D_{e z}=D_{e x} / 2\right)$ and calculated vertical effective diffusion coefficients of chloride used for both. Error bars for chloride concentrations represent $\pm 10 \%$.

taken as a reference). While hydraulic head of the upper unit (Aalenian) is kept constant over time, that of the lower boundary steadily decreases at a rate of $\sim 46 \mathrm{~m} \mathrm{Ma}^{-1}$, reaching a value of $463 \mathrm{~m}$ at the present time. This rate of decrease in hydraulic head is very high compared to typical rates of erosion (generally between 4.6 and $7.2 \mathrm{~m} \mathrm{Ma}^{-1}$ [Daniels and Hammer, 1992]) but it includes both erosion and lowering of sea level over the last $3 \mathrm{Ma}$. Hydraulic conductivities are determined so that calculated hydraulic heads agree with experimental data at the final stage (Figure 8). $K\left(\mathrm{~m} \mathrm{~s}^{-1}\right)$ values used in simulations are $10^{-9}$ for the Aalenian, $0.8 \times 10^{-14}$ for the upper and middle part of the Upper Toarcian $2.3 \times 10^{-14}$ for the lower part of the Upper Toarcian, $2 \times 10^{-14}$ and $0.8 \times 10^{-14}$ for the Middle, Lower Toarcian respectively, and $0.9 \times 10^{-14}$ for the Domerian (Figure 6).

[48] Modeling results for pore water chloride concentrations (Figure 9a) most closely agree with experimental data when using chloride diffusion coefficients $2 \times 10^{-14}$ to $3 \times$ $10^{-12}$ (Figure 9b). Indeed, except for those in the Aalenian, diffusion coefficients obtained from the calibration of the model are the same order of magnitude as experimental data (Figure 10).

[49] Despite the fact that this simulation produces the best agreement with data on chloride concentrations, those in Aalenian and Lower Toarcian are only approximately reproduced. Data from the Aalenian, for example, yield generally higher values than calculated concentrations. This difference may reflect the presence of sedimentary heterogeneities in the geological formation such as calcareous nodules, which are numerous in the very upper part of
Upper Toarcian and in Aalenian units, and contain pore water with high chloride concentrations. This type of chloride heterogeneity is difficult to represent in such a model. Moreover, horizontal dispersion of chloride data in the Middle Toarcian, and lack of data in the Domerian are both drawbacks to fitting the model in the Lower Toarcian.

\subsubsection{Modeling With Assumption of Pure Diffusion} Over 53 Ma

[50] Simulations of chloride transport solely by diffusion over the past $53 \mathrm{Ma}$ are performed using the same initial

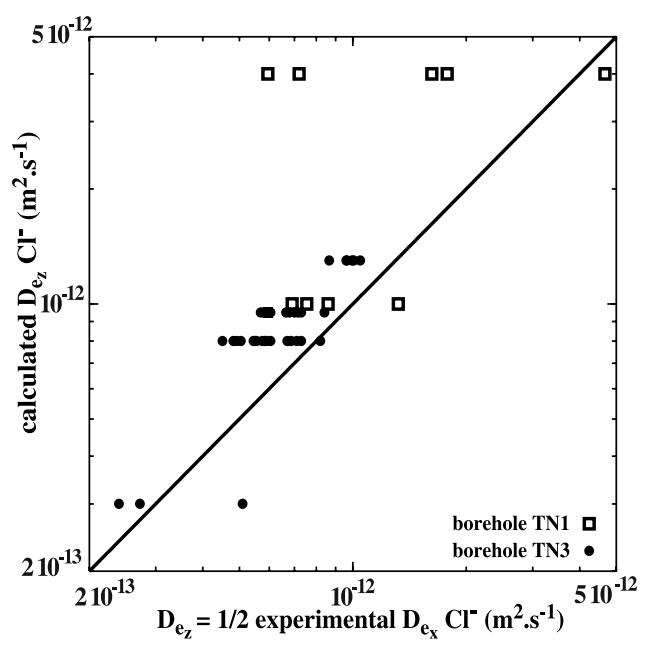

Figure 10. Calculated vertical effective diffusion coefficients used for simulations of chloride transport plotted as a function of measured values $\left(D_{e z}=D_{e x} / 2\right)$. 
and boundary conditions described above, as are chloride diffusion coefficients. Comparison of calculated concentrations from the pure diffusion simulation (Figure 9a) and those from simulation with fluid flow over the last $3 \mathrm{Ma}$ suggests that the impact of fluid flow on the chloride transport is very low. Largest differences occur in Domerian units, which appear as a slight bulging of the profile. Considering that 3 out of $53 \mathrm{Ma}$ is a relatively short period of time, and considering the low hydraulic conductivities of the argillites and marls, it is not surprising to observe such a small effect. Nonetheless, chloride concentrations from simulation taking into account fluid flow are closer to experimental values in the Lower Toarcian.

\subsection{Discussion About the Calibration and Conclusion About the Diffusion as the Main Process for Mass Transport}

[51] Assessment of the validity of transport modeling established by minimizing differences between computed and experimental chloride concentrations, is evaluated by examining the coherence of calculated and experimental chloride diffusion coefficients. Calculated diffusion coefficients are, for all levels of the geological sequence, in a good agreement with experimental coefficients. Despite horizontal dispersion of experimental data at various levels (that one-dimensional diffusion models are unable to reproduce), diffusion clearly appears to be the main process of chloride transport through these argillites. Downward fluid flow during the last $3 \mathrm{Ma}$ has not dramatically changed the chloride concentration profile, but does result in a slight improvement in the lower part of the sequence.

[52] These simulations also show that it is quite difficult to reproduce data in the lower part of the sequence, because the groundwater flow in the Carixian layer probably started later than in the Aalenian layer, which is more superficial. It would be necessary to derive more accurate hydro-geological history of the massif, and to obtain more data on chloride concentrations and diffusion coefficients at these lower levels, in order to better-constrain the model.

\section{Deuterium Simulations: Tests of Two Boundary Condition Scenarios}

[53] Chloride simulations show that the conceptual model proposed in section 2.2, offers adequate explanation for the current profile of chloride concentrations (according to the timescale considered and according to parameters and constant boundary conditions used for chloride simulations). Given this agreement, it is interesting to assess the sensitivity of the model using a second tracer. We have chosen deuterium (more precisely ${ }^{2} \mathrm{H}^{1} \mathrm{H}^{16} \mathrm{O}$ ) as this tracer because on one hand it obeys relatively simple fractionation relations and on the other hand it is part of the water molecule.

\subsection{Data Acquisition}

[54] As with chloride, deuterium content was measured on samples of Tournemire argillites interstitial water. Several data sets constitute the vertical profile of deuterium across this succession; two studies [Michelot and Errarhaoui, 2000; Patriarche, 2001] obtained samples from boreholes TN1 and $\mathrm{TN} 3$, in addition to the original data set completed on samples from boreholes ID [Moreau-Le Golvan, 1997].
Methods of water extraction from rock samples can significantly affect the accuracy of obtained data, especially in the case of rocks with very low water content, such as the Tournemire argillites. Owing to the importance of these issues, several techniques have been developed to extract water from rock samples; none is completely satisfactory [Sacchi et al., 2001]. For all of the data sets used here, interstitial water was extracted using the vacuum distillation technique. Moreau-Le Golvan et al. [1997] evaluated this technique, and showed that water extraction is influenced by temperature, sample grain sizes, and by the amount of time that a crushed sample is in contact with the atmosphere. They concluded that these variables might have a significant influence, especially on the ${ }^{18} \mathrm{O}$ content of water. In order to minimize disadvantages inherent in vacuum distillation, temperatures of water extraction were limited to $50^{\circ} \mathrm{C}$, and the entire crushed sample was used for vacuum distillation. Duration of contact between samples and the atmosphere was minimized by processing no more than 4 samples at a time. Once interstitial water was obtained, ${ }^{18} \mathrm{O}$ and ${ }^{2} \mathrm{H}$ content were measured by mass spectrometry. ${ }^{2} \mathrm{H}$ content analysis was done on $\mathrm{H}_{2}$ obtained after reduction of water by $\mathrm{Zn}$ [Coleman et al., 1982]. ${ }^{18} \mathrm{O}$ analysis was done on $\mathrm{CO}_{2}$ obtained after water equilibration with ${ }^{18} \mathrm{O}$ marked $\mathrm{CO}_{2}$ [Epstein and Mayeda, 1953]. Results (Figure 11a) are expressed as \%o deviation ( $\delta$ notation) relative to the V-SMOW standard for oxygen 18 and deuterium as reported by Baertschi [1976] and by Hagemann et al. [1970], respectively.

\subsection{Initial and Boundary Conditions for Deuterium}

\subsubsection{Initial Deuterium Content of Interstitial Water}

[55] As it was the case for chlorine, the model assumes that initial water in Toarcian and Domerian units was seawater. Early Cretaceous seawater deuterium concentration is assumed equal to that of modern seawater (typically $0 \%$ ).

5.2.2. Deuterium Content of Water at the Boundaries

[56] Present-day deuterium content of rainwater circulating in the karstic units is about $-50 \%$ o. Considering that $\delta^{2} \mathrm{H}$ values in the upper part of Toarcian range to $-83 \%$, it appears impossible to reproduce the data profile with $-50 \%$ as a deuterium boundary condition. Using the lowest deuterium interstitial water value from Tournemire samples $(-83 \%$ ) would be an arbitrary choice corresponding to no physical reality and would not help to explain the higher $\delta^{2} \mathrm{H}$ values in Aalenian units.

[57] We therefore tested deuterium transport models using two sets of boundary conditions, wherein deuterium varies over time. Because $\delta^{2} \mathrm{H}$ in precipitation covaries with temperature [see Clark and Fritz, 1997], we assess major temperature change over the last $53 \mathrm{Ma}$ and use two deuterium-temperature relationships to estimate deuterium content in precipitation over time.

[58] Paleoclimate reconstructions are quite good for very recent time periods. For instance, isotopic compositions of high latitude precipitation are well known for the past $160 \mathrm{ka}$ from data on Vostok (Antarctica) or Camp Century (Greenland) ice cores [Oeschger and Mintzer, 1993]. However, as we go back in time, major climate changes are less and less well constrained. Paradoxically, recently, scientists essentially focused their attention more on aberrations of past climates than on its main trend [Zachos et al., 2001]. 

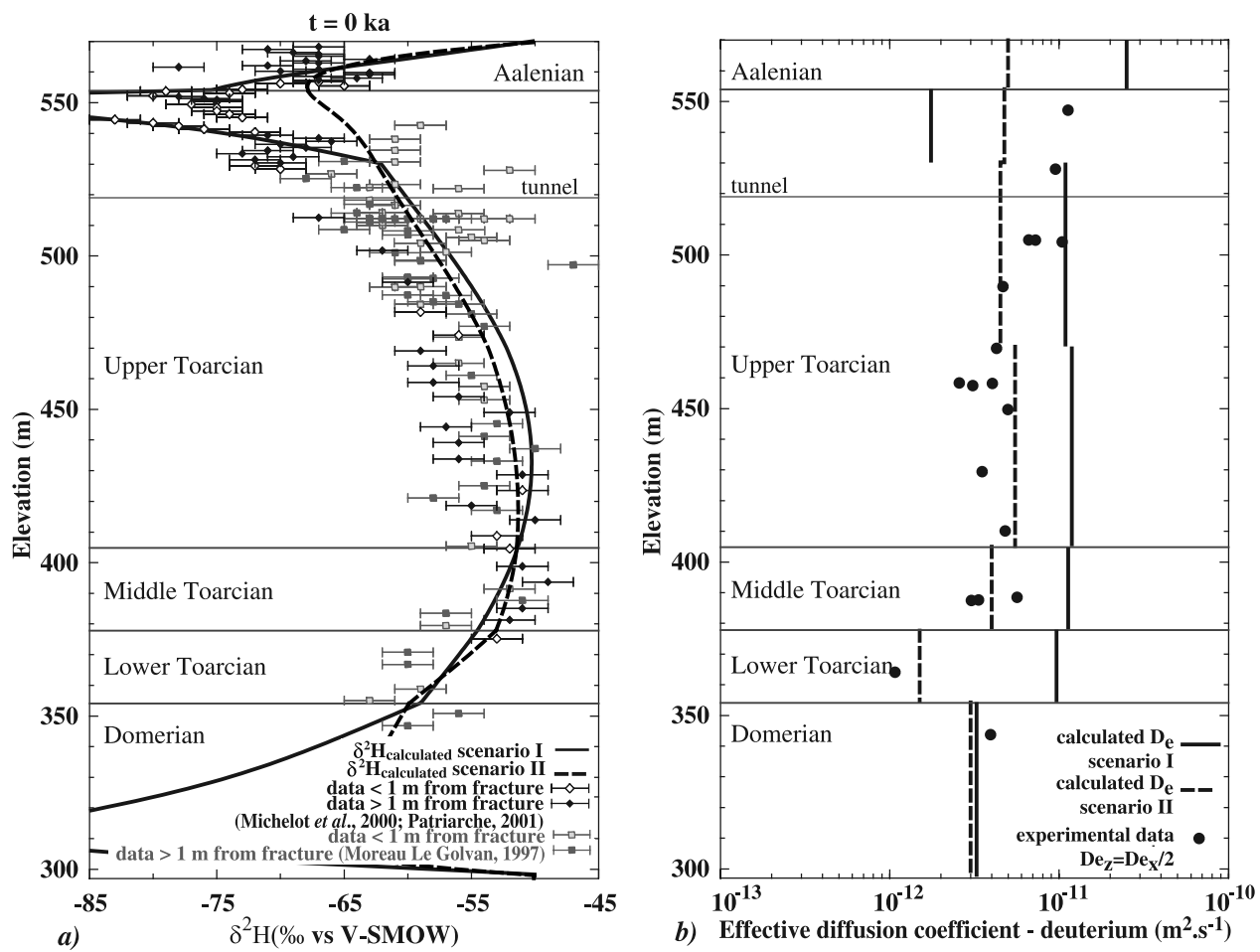

Figure 11. (a) Experimental and calculated deuterium contents in interstitial water at the present time and (b) experimental $\left(D_{e z}=D_{e x} / 2\right.$, data from Beaudoing et al. $\left.[1994,1996]\right)$ and calculated vertical effective diffusion coefficients of deuterium for simulations using diffusion over the past $53 \mathrm{Ma}$ and fluid flow over the last $3 \mathrm{Ma}$, with the boundary scenarios using $\delta^{2} \mathrm{H}=5.6 \mathrm{MAT}-100$ (scenario I, solid lines) and using $\delta^{2} \mathrm{H}=1.76 \mathrm{MAT}-70$ (scenario II, dashed lines). Error bars for deuterium content represent a standard deviation of $\pm 2 \%$.

Despite difficulties for taking into account all processes playing a role in climatic regulation [Pierrehumbert, 2002], advances in climate modeling using recent observed data, historical records, and geologic proxy data (biological, sedimentological, geochemical...) might provide information on past climates, and more recently even allow for predictions under assumptions. In order to estimate the deuterium content in precipitation, temperatures (Figure 4) are assessed for the past $53 \mathrm{Ma}$ using calculated temperatures obtained by Crowley and Kim [1995] (also recently cited by Barrett [2003]), which are inferred from data given by Zachos et al. [1994] and Sellwood et al. [1994] for Eocene and Cenomanian, respectively. These temperatures are in very good agreement with temperatures given for southern Europe by Ivanov et al. [2002] and Mai [2000] for the Middle and Upper Miocene and by Fauquette et al. [1999] and Haywood et al. [2000] for the Pliocene. Adjustments to temperatures given by Crowley and Kim [1995] are also introduced; Mai [2000] gives European mean annual temperatures of $17^{\circ} \mathrm{C}$ and $11^{\circ} \mathrm{C}$ for Middle Eocene and Pliocene, respectively. For the Quaternary, temperatures given by Frakes [1979] are used (Figure 4; timescale from Foucault and Raoult [1995]).

[59] The relation between mean annual temperature (MAT) and the $\delta^{18} \mathrm{O}$ and $\delta^{2} \mathrm{H}$ of modern meteoric water is well known for the Northern Hemisphere [International Atomic Energy Agency and World Meteorological Organization, 2001], and is expressed as $\delta^{2} \mathrm{H}=5.6 \mathrm{MAT}-100$ [Dansgaard, 1964]. The second relation is $\delta^{2} \mathrm{H}=1.76$ MAT
-70 and is from $\delta^{2} \mathrm{H}=8 \delta^{18} \mathrm{O}+10$ [Craig, 1961] and $\delta^{18} \mathrm{O}=0.22 \mathrm{MAT}-10$ [Huneau, 2000]. The latter relation comes from noble gas analyses of groundwater from the Valréas Basin (south of France), ${ }^{14} \mathrm{C}$ dated between 0 and $25 \mathrm{ka} \mathrm{BP}$. We decided to use this relation to estimate paleo$\delta^{2} \mathrm{H}$ compositions of meteoric precipitation because of the proximity of the Valréas Basin to the Tournemire site, and because this relation is consistent with $\delta^{18} \mathrm{O}=0.26$ MAT 9.5 given by Philippot et al. [2000] for the Mol site (Belgium). Both relations have slopes that are similar to those obtained by Edmunds et al. [1997] $\left(0.28^{\circ} \mathrm{C} / \%\right.$ o $)$ and Rozanski et al. [1992] $\left(0.37^{\circ} \mathrm{C} / \% 0\right)$.

[60] The "reconstruction" of deuterium content in precipitation (Figure 4) is based on paleotemperatures noted above and these two relations $\left(\delta^{2} \mathrm{H}=5.6\right.$ MAT -100 for scenario I and $\delta^{2} \mathrm{H}=1.76 \mathrm{MAT}-70$ for scenario II).

\subsection{Simulations}

[61] Deuterium transport simulations include fluid flow effect over the last $3 \mathrm{Ma}$ : hydraulic conductivities ranged from $10^{-13}$ to $10^{-11} \mathrm{~m}^{2} \mathrm{~s}^{-1}$. Results of both simulations using the Dansgaard and the Craig-Huneau temperature- $\delta^{2} \mathrm{H}$ relations derive a best fitted curve for deuterium content in interstitial water, and calculated deuterium diffusion coefficients (Figure 11).

[62] The Dansgaard relation yields calculated diffusion coefficients (Figure 12) that are more than one order of magnitude above experimental values except for the calculated diffusion coefficient in the Upper Toarcian that is 


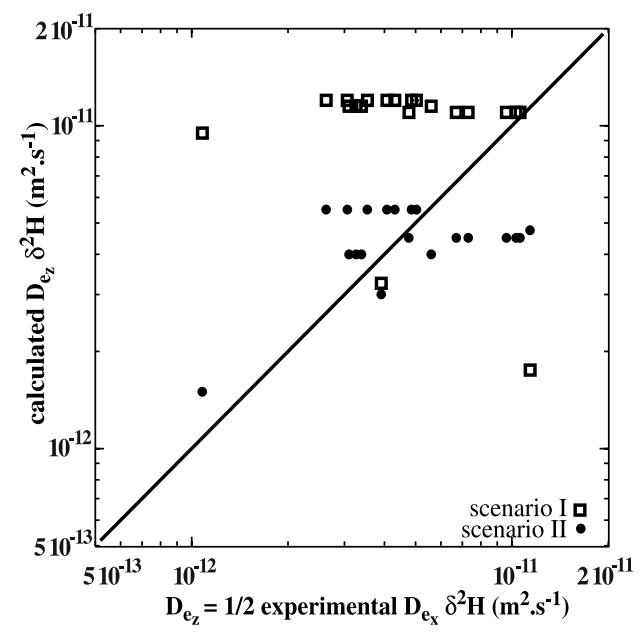

Figure 12. Calculated vertical effective diffusion coefficients of deuterium used for simulations of deuterium transport using diffusion over the past $53 \mathrm{Ma}$ and fluid flow over the last $3 \mathrm{Ma}$, with the boundary scenarios using $\delta^{2} \mathrm{H}=$ 5.6 MAT - 100 (scenario I, squares) and using $\delta^{2} \mathrm{H}=1.76$ MAT - 70 (scenario II, dots), plotted as a function of measured values $\left(D_{e z}=D_{e x} / 2\right.$, data from Beaudoing et al. [1994, 1996]).

lower than the experimental data in this unit. The simulation using the temperature- $\delta^{2} \mathrm{H}$ relation from Craig [1961] and Huneau [2000] shows that calculated diffusion coefficients are in good agreement in the entire sequence. However, despite the fact that the calculated diffusion coefficient in the upper part of the Upper Toarcian is in the same order of magnitude with the experimental data, calculated concentrations are not reproduced in the upper part of the sequence (Figure 11b). Indeed, it was not possible to fit the model on the experimental concentration profile in the upper part of the sequence notably because the lowest concentration applied at the boundary for the scenario II $(-78.8 \%$ ) is already higher than the lowest deuterium content at the Aalenian/Toarcian boundary $(-80 \%)$.

\subsection{Discussion}

\subsubsection{Deuterium Simulations}

[63] Generally speaking, these simulations show that the model is more sensitive to tracer diffusion coefficients of layers located near the boundaries of the system than to those of layers located in the middle of the massif.

[64] Despite the fact that both temperature- $\delta^{2} \mathrm{H}$ relations can reproduce the "bow" shape of the deuterium concentration profile, deuterium simulations are unable to reproduce specific points deviating from the general trend. Indeed, several upper part of Upper Toarcian samples are enriched in deuterium compared to interstitial water of samples at the same level. Moreau-Le Golvan et al. [1997] observed that horizontal dispersion of deuterium concentration occurs along some levels in the massif. Because most of these samples were collected less than one meter from a fracture, they suggested that fractures could be related to the isotopic enrichment of water. This is reinforced by the fact that horizontal dispersion cannot be explained by imprecision in deuterium analyses or lateral variations in porosities and/or diffusion coefficients.
[65] Both deuterium simulations present difficulties to insure consistency between concentrations and diffusion coefficients at the upper system boundary (Aalenian and upper part of Upper Toarcian). The presence of numerous fractures in the upper part of the Upper Toarcian could not only result in vertical shifting of the hydrologic boundary, but could also create horizontal mass transport (either if these fractures are directly connected to the upper aquifer or if they are connected to a lower part of the massif).

[66] Discrepancies between deuterium diffusion coefficients obtained from the calibration of the model and available experimental data indicate that the use of either temperature- $\delta^{2} \mathrm{H}$ relation is probably invalid. This is not surprising considering the fact that both relations are derived from data spanning relatively short periods of time, but were then used over a geologic history of $53 \mathrm{Ma}$. It should be also noted that seasonal variation for the infiltration rate of water and seasonal variations of deuterium content in precipitation might have an influence, which is out of range of our modeling capability.

\subsubsection{Comparison of Chloride and Deuterium}

\section{Transport}

[67] Despite similar pore diffusion coefficients $\left(\sim 10^{-12}\right.$ $\mathrm{m}^{2} \mathrm{~s}^{-1}$ ), chloride and deuterium have different behaviors in term of fluxes through argillites. Indeed, because chloride accessible (geochemical) porosity is smaller than that for deuterium, effective diffusion coefficients are smaller as well. This implies that the diffusion front velocity is higher for deuterium than for chloride. In term of mass fluxes, concentration gradient has to be taken into account when comparing whiles needed for reaching a flat "ideal" shape (section 2.3). Calculations for both tracers performed with invariant conditions at the system boundaries show that diffusion of deuterium through the impermeable units is faster than that of chloride. However, variable conditions of deuterium system boundaries imply that while a flat profile cannot be reached for deuterium, it can be attained for chloride simulations, which are performed using the "reasonable" hypothesis that chloride concentrations at the system boundaries could have stay constant over time.

[68] However, in spite of scattered concentrations in the upper part of the geological sequence not well represented by the model, diffusion can explain the general distribution of deuterium concentrations. At this geological level, the highest deuterium content is associated to samples collected at vicinity of from fractures where local circulations could have occurred and may have affected deuterium concentrations. This effect is not perceptible for chloride concentrations perhaps because samples for chloride analysis were collected from boreholes TN1 and TN3 that encountered only small and dry fractures.

\section{Conclusion}

[69] Two extensive databases on interstitial water chloride concentrations and chloride diffusion coefficients (part 1 of this study) lead to a conceptual model for mass transport trough Tournemire argillites in which molecular/ionic diffusion is playing the main role. On the basis of current knowledge of the geological history of the Tournemire massif, chloride transport modeling is in a good agreement 
with available experimental data. Indeed, diffusion coefficients calculated when obtaining the best fit between modeled and measured chloride concentrations are closed to diffusion coefficients measured from rock samples over the entire sequence. While model distribution of diffusion coefficients in agreement with measured chloride concentrations are not unique, good agreement between these and measured coefficients confirms the hypothesis that diffusion is high likely the main process for mass transport through impermeable layers of the Tournemire massif.

[70] Nonetheless, assuming that chloride concentrations at the system boundaries have remained constant, the low values of chloride diffusion coefficient obtained as a result of the model calibration suggest that there might be some problems with the lower boundary condition, such as the fact that the functioning of the deep aquifer started later than the one of the shallow, implying that low concentration values have been imposed during a shorter time at the basis of the argillites.

[71] Simulations incorporating temporally variable deuterium concentrations are more difficult to reconcile with pore water $\delta^{2} \mathrm{H}$ data from impermeable units. Model deuterium diffusion coefficients calculated for the Dansgaard scenario are about one order of magnitude higher than measured values. However, the temperature- $\delta^{2} \mathrm{H}$ relation derived from noble gas data appears to be more suitable (Figure 11b), because in this scenario, discrepancies between calculated and experimental diffusion coefficients appear essentially on the upper and middle part of the Upper Toarcian were fractures are present. Given our current knowledge of both the geological history of this region, and the evolution of deuterium in precipitation, models that span such long periods of time are still difficult to calibrate.

[72] Although diffusion can readily explain the general distribution of deuterium and chloride concentrations, current numerical transport modeling is not able to reproduce the horizontal dispersion of concentration data that exists at specific levels. In order to refine such models, heterogeneities in the system have to be taken into account. A two-dimensional model that includes lithologic heterogeneities and fractures would probably result in a better representation of horizontal variations of both chloride and deuterium concentrations. Models incorporating the presence of other heterogeneities such as calcareous nodules which are a probable source of chloride, would be more difficult to formulate because the size and distribution of such nodules in the geological sequence are not well know. Studies of both types of heterogeneities at smaller scales (from metric to micrometric) would be useful for a better understanding of local processes involving chloride and deuterium in mass transport near the fractures, and for their representation in the model of mass transport.

\section{Notation}

$\theta$ water content in weight, $\%$.

$\omega_{\theta}$ total porosity derived from water content, $\%$.

$\omega_{e}$ effective porosity where advection and dispersion occurs, $\%$.

$\omega_{d}$ diffusion porosity for a chemical species, $\%$.

$\omega_{\text {geoch }}$ geochemical porosity for a chemical species, $\%$.
$D_{p}$ pore diffusion coefficient, $\mathrm{m}^{2} \mathrm{~s}^{-1}$.

$D_{e}$ effective diffusion coefficient, $\mathrm{m}^{2} \mathrm{~s}^{-1}$.

$z$ elevation, $\mathrm{m}$.

$z_{c}$ corrected elevation (boreholes TN1 and TN3 taken as reference), $\mathrm{m}$.

$K$ hydraulic conductivity, $\mathrm{m} \mathrm{s}^{-1}$.

$D_{0}$ diffusion coefficient of a chemical species in free-water, $\mathrm{m}^{2} \mathrm{~s}^{-1}$.

$h$ hydraulic head, $\mathrm{m}$.

C concentration, $\mathrm{mol} \mathrm{L}^{-1}$.

MAT Mean Annual Temperature, ${ }^{\circ} \mathrm{C}$.

$\delta$ notation expressing \% deviation relative to standard.

[73] Acknowledgments. We wish to thank Justo Cabrera and Annick Filly for the technical support and Patrick Goblet for his continuous help throughout this project. The thorough and constructive reviews provided by two anonymous reviewers and the comments of Bruce H. Wilkinson on an earlier version of this manuscript are greatly appreciated. We are also grateful to Ghislain de Marsily for his advices and to Maria Clara Castro for the support she provided during the completion of this article.

\section{References}

Ambert, M., and P. Ambert (1995), Karstification des plateaux et encaissement des vallées au cours du Néogène et du Quaternaire dans les Grands Causses méridionaux (Larzac, Blandas), Geol. Fr., 4, 37-50.

Baertschi, P. (1976), Absolute oxygen-18 content of standard mean ocean water, Earth Planet. Sci. Lett., 31, 341-344.

Barrett, P. (2003), Paleoclimatology; Cooling a continent, Nature, 421, $221-223$.

Beaudoing, G., B. Dubing, and M. Launay (1994), Coefficients de diffusion et de perméation $(\mathrm{dP}=1,5 \mathrm{MPa})$ d'eau déminéralisée à travers deux types d'échantillons du sous-sol de Tournemire, Rep. 94/30/GB, Comm. à l'Energie Atomique, Dép. des Appl. et de la Métrol. des Rayonnements Ionisants, Grenoble, France.

Beaudoing, G., S. Moutin, M. Launay, and B. Dubing (1996), Coefficients de diffusion et de perméation $(\mathrm{dP}=1,5 \mathrm{MPa})$ d'eau à travers des échantillons d'argile du site de Tournemire, 96/32, Comm. à l'Energie Atomique, Dép. des Appl. et de la Métrol. des Rayonnements Ionisants, Grenoble, France.

Blanc, J.-J. (1997), Géodynamique et histoire du karst - Application au sud-est de la France, Quaternaire, 8(2-3), 91-105.

Boisson, J.-Y., J. Cabrera, and L. De Windt (1998), Etude des écoulements dans un massif argileux, laboratoire souterrain de Tournemire, Rep. EUR 18338, Eur. Comm., Luxembourg.

Boisson, J.-Y., L. Bertrand, J.-F. Heitz, and Y. Moreau-Le Golvan (2001), In situ and laboratory investigations of fluid flow trough an argillaceous formation at different scales of space and time, Tournemire tunnel, southern France, Hydrogeol. J., 9, 108-123.

Bruxelles, L. (2001), Dépôts et altérites des plateaux du Larzac central: Causse de l'Hospitalet et de Campestre (Aveyron, Gard, Hérault). Evolution morphogénique, conséquences géologiques et implications pour l'aménagement, Ph.D. thesis, Univ. de Provence, Aix-en-Provence, France.

Clark, I. D., and P. Fritz (1997), Environmental Isotopes in Hydrogeology, 328 pp., CRC Press, Boca Raton, Fla.

Coleman, M. L., T. J. Sheperd, J. J. Durham, J. E. Rouse, and G. R. Moore (1982), Reduction of water with zinc for hydrogen isotope analysis, Anal. Chem., 54(6), 993-995.

Cordier, E., and P. Goblet (1999), Programme METIS - Simulation d'écoulement et de transport miscible en milieu poreux et fracturé-Notice d'emploi, Rep LHM/RD/99/18, Cent. d'Inf. Géol., Ecole Natl. Supérieure des Mines de Paris, Fontainebleau, France.

Craig, H. (1961), Standard for reporting concentration of deuterium and oxygen-18 in natural waters, Science, 113, 1833-1834.

Crowley, T. J., and K.-Y. Kim (1995), Comparison of longterm greenhouse projections with the geologic record, Geophys. Res. Lett., 22(8), $933-$ 936.

Daniels, R. B., and R. D. Hammer (1992), Soil Geomorphology, 236 pp., John Wiley, Hoboken, N. J.

Dansgaard, W. (1964), Stable isotopes in precipitation, Tellus, 16, 436468 . 
Degueldre, C., A. Scholtis, A. Laube, M. J. Turrero, and B. Thomas (2003), Study of the pore water chemistry through an argillaceous formation: A paleohydrochemical approach, Appl. Geochem., 18(1), 55-73.

de Marsily, G., P. Combes, and P. Goblet (1992), Comment on "Groundwater models cannot be validated by L. F. Konikow and J. D. Bredehoeft, Adv. Water Res., 15(6), 367-369.

Derruau, M. (1973), The morphology of the Central Massif (in French), in The Geology, Geomorphology and Deep Structure of the French Central Massif, pp. 33-44, Plein Air Service Ed., Clermont-Ferrand, France.

Desaulniers, D. E., J. A. Cherry, and P. Fritz (1981), Origin, age and movement of pore water in argillaceous Quaternary deposits at four sites in southwestern Ontario, J. Hydrol., 50, 231-257.

Douglas, R. G., and F. Woodruff (1981), Deep-sea benthic foraminifera, in The Oceanic Lithosphere, pp. 1233-1327, John Wiley, Hoboken, N. J.

Edmunds, W. M., E. Fellman, I. Baba Goni, G. McNeill, and D. D. Harkness (1997), Groundwater, palaeoclimate and palaeorecharge in the southwest Chad Basin, Borno State, Nigeria, in Isotope Techniques in the Study of Environmental Change, pp. 693-707, Int. Atomic Energy Agency, Vienna.

Epstein, S., and T. Mayeda (1953), Variation of $\mathrm{O}^{18}$ content of waters from natural sources, Geochim. Cosmochim. Acta, 4(5), 213-224.

Falck, W. E., A. H. Bath, and P. J. Hooker (1990), Long term solute migration profiles in clay sequences, Z. Dtsch. Geol. Ges., 141, 415426.

Fauquette, S., J.-P. Suc, J. Guiot, F. Diniz, N. Feddi, Z. Zheng, E. Bessais, and A. Drivaliari (1999), Climate and biomes in the west Mediterranean area during the Pliocene, Palaeogeogr. Palaeoclimatol. Palaeoecol., $152(1-2), 15-36$.

Foucault, A., and J.-F. Raoult (1995), Dictionnaire de Géologie, 324 pp., Masson, Paris.

Frakes, L. A. (1979), Climate Throughout Geologic Time, Elsevier Sci., New York

Goblet, P. (1989), Programme METIS-Simulation d'écoulement et de transport miscible en milieu poreux et fracturé-Notice de conception, Rep. LHM/RD/89/23, Cent. d'Inf. Géol., Ecole Natl. Supérieure des Mines de Paris, Fontainebleau, France.

Hagemann, R., G. Nief, and E. Roth (1970), Absolute isotopic scale for deuterium analysis of natural waters: Absolute $\mathrm{D} / \mathrm{H}$ ratio for SMOW, Tellus, 22(6), 712-715.

Harrington, G. A., A. J. Love, and A. L. Herczeg (2001), Relative importance of physical and geochemical processes affecting solute distributions in a clay aquitard, in Proceedings of the 10th International Symposium on Water-Rock Interaction, edited by R. Cidu, pp. $177-$ 180, Swets and Zeitlinger, Lisse, Netherlands.

Haywood, A. M., B. W. Sellwood, and P. J. Valdes (2000), Regional warming; Pliocene $(3 \mathrm{Ma})$ paleoclimate of Europe and the Mediterranean, Geology, 28(12), 1063-1066.

Hendry, M. J., and F. W. Schwartz (1988), An alternative view on the origin of chemical and isotopic patterns in groundwater from the Milk River Aquifer, Canada, Water Resour. Res., 24(10), 1747-1763.

Hendry, M. J., and L. I. Wassenar (1999), Implications of the distribution of $\delta^{2} \mathrm{H}$ in pore waters for groundwater flow and the timing geologic events in a thick aquitard system, Water Resour. Res., 35(6), 1751-1760.

Hinch, H. H. (1980), The nature of shales and the dynamics of hydrocarbon expulsion in the Gulf Coast Tertiary section, Problems of Petroleum Migration, AAPG Stud. Geol, vol. 10, pp. 1-18, Am. Assoc. of Pet. Geol., Tulsa, Okla.

Huneau, F. (2000), Fonctionnement hydrogéologique et archive paléoclimatique d'un aquifère profond méditerranéen, Ph.D. thesis, Univ. d'Avignon, Avigon, France.

International Atomic Energy Agency and World Meteorological Organization (2001), Global Network of Isotopes in Precipitation: GNIP Database, Vienna.

Ivanov, D., A. R. Ashraf, V. Mosbrugger, and E. Palamarev (2002), Palynological evidence for Miocene climate change in the Forecarpathian Basin (central Paratethys, NW Bulgaria), Palaeogeogr. Palaeoclimatol. Palaeoecol., 178(1-2), 19-37.

Kitanidis, P. T. (1997), Comment on "A reassessment of the groundwater inverse problem" by D. McLauglin and L.R. Townley, Water Resour Res., 33(9), 2199-2202.

Konikow, L. F., and J. D. Bredehoeft (1992), Ground-water models cannot be validated, $A d v$. Water Res., 15(1), 75-83.

Lippmann, J., A. Rübel, K. Osenbrück, C. Sonntag, and M. Gröning (1998), Dating porewater in rocks samples from fresh drilling cores-
Depth profiles of stable isotopes, noble gases and chloride in hydraulically impermeable geological formations, in Isotope Techniques in the Study of Past and Current Environmental Changes in The hydrosphere and the Atmosphere: Proceedings of an International Symposium Held in Vienna, 14-18 April 1997, pp. 465-472, Int. Atomic Energy Agency, Vienna.

Mai, D. H. (2000), Palm trees in the past; paleoclimatological and paleoecological indicators, GFF, 122(1), 97-98.

Maloszewski, P., and A. Zuber (1993), Principles and practice of calibration and validation of mathematical models for the interpretation of environmental tracer data in aquifers, Adv. Water Res., 16, 173-190.

McLaughlin, D., and L. R. Townley (1996), A reassessment of the groundwater inverse problem, Water Resour. Res., 32(5), 1131-1161.

McLaughlin, D., and L. R. Townley (1997), Reply to comment by P.K. Kitanidis on "A reassessment of the groundwater inverse problem,", 33(9), 2203-2204

Meybeck, M. (1984), Les fleuves et le cycle géochimique des éléments, $\mathrm{Ph} . \mathrm{D}$. thesis, Univ. Pierre et Marie Curie (Paris VI), Paris.

Michelot, J.-L., and K. Errarhaoui (2000), Compléments d'analyses isotopiques sur les fluides issus de la formation de Tournemire, Rap. Intermédiaire Cont. 4060 0B018940/SH, Univ. Paris-Sud, Orsay, France.

Moreau-Le Golvan, Y. (1997), Traçage isotopique naturel des transferts hydriques dans un milieu argileux de très faible porosité: Les argilites de Tournemire (France), Ph.D. thesis, Univ. Paris-Sud, Orsay, France.

Moreau-Le Golvan, Y., J.-L. Michelot, and J.-Y. Boisson (1997), Stable isotope contents of porewater in a claystone formation (Tournemire, France): Assessment of the extraction technique and preliminary results, Appl. Geochem., 12, 739-745.

Neuzil, C. E. (2000), Osmotic generation of "anomalous" fluid pressures in geological environments, Nature, 403, 182-184.

Oeschger, H., and I. M. Mintzer (1993), Lessons from the ice cores; rapid climate changes during the last 160,000 years, in Confronting Climate ChangeL: Risk, Implications and Responses, pp. 55-64, Cambridge Univ. Press, Cambridge, U. K.

Patriarche, D. (2001), Caractérisation et modélisation des transferts de traceurs naturels dans les argilites de Tournemire, Ph.D. thesis, Ecole Natl. Supérieure des Mines de Paris, Fontainebleau, France.

Patriarche, D., J.-L. Michelot, E. Ledoux, and S. Savoye (2004), Diffusion as the main process for mass transport in very low water content argillites: 1. Chloride as a natural tracer for mass transport-Diffusion coefficient and concentration measurements in interstitial water, Water Resour. Res., 40, doi:10.1029/2003WR002600, in press.

Pearson, F. J. (1999), What is the porosity of a mudrock?, in Muds and Mudstones: Physical and fluid Flow Properties, edited by A. C. Aplin, A. J. Fleet, and J. H. S. Macquaker, Geol. Soc. Spec. Publ., $158,9-21$.

Philippot, A.-C., J.-L. Michelot, and C. Marlin (2000), A palaeohydrogeological study of the Mol site, Belgium (PHYMOL project), rapport spécifique 3, Analyse des isotopes stables et des gaz nobles, Rep. DOC RTD/55/2000, Dir. Gen. de la Rech., Eur. Comm., Brussels.

Pierrehumbert, R. T. (2002), The hydrologic cycle in deep-time climate problems, Nature, 419, 191-198.

Rozanski, K., L. Araguás-Araguás, and R. Gonfiantini (1992), Relation between long-term trends of oxygen-18 isotope composition of precipitation and climate, Science, 258, 981-985.

Rübel, A. P. (2000), Stofftransport in undurchlässigen GesteinsschichtenIsotopenuntersuchungen im grund- und porenwasser, Ph.D. thesis, Heidelberg Univ., Heidelberg, Germany.

Rübel, A. P., C. Sonntag, J. Lippmann, F. J. Pearson, and A. Gautschi (2002), Solute transport in formations of very low permeability: Profiles of stable isotope and dissolved noble gas contents of pore water in the Opalinus Clay, Mont Terri, Switzerland, Geochim. Cosmochim. Acta, 66(8), 1311-1321.

Sacchi, E., J.-L. Michelot, H. Pitsch, P. Lalieux, and J.-F. Aranyossy (2001), Extraction of water and solutes from argillaceous rocks for geochemical characterisation: methods, processes, and current understanding, Hydrogeol. J., 9, 17-33.

Schoeller, M. (1961), Calcul du bilan des nappes d'eau des "Sables des Landes" en utilisant la teneur en chlore de l'eau des nappes et celle de l'eau de pluie, C. R. Acad. Sci. Paris, 253(15), 1598-1599.

Sellwood, B. W., G. D. Price, and P. J. Valdes (1994), Cooler estimates of Cretaceous temperatures, Nature, 370, 453-455.

Simon-Coinçon, R., and J.-M. Schmitt (1999), Evolution géologique et histoire paléoenvironnementale du bassin des Grands Causses, Rep. 
LHM/RD/99/10, Cent. d'Inf. Géol., Ecole Natl. Supérieure des Mines de Paris, Fontainebleau, France.

Stone, W. J. (1992), Paleohydrological implications of some deep soilwater chloride profiles, Murray Basin, South Australia, J. Hydrol., 132, $201-$ 223.

Waber, N. H. (2001), Sondierbohrung Benken: Untersuchungsbericht, investigation report, Natl. Coop. for the Disposal of Radioactive Waste, Wettingen, Switzerland.

Wang, J. H., C. V. Robinson, and I. S. Edelman (1953), Self-diffusion and structure of liquid water. III Measurement of the self-diffusion of liquid water with $\mathrm{H}^{2}, \mathrm{H}^{3}$ and $\mathrm{O}^{18}$ as tracers, J. Am. Chem. Soc., 75, $466-470$.

Zachos, J. C., L. D. Stott, and K. C. Lohmann (1994), Evolution of early Cenozoic marine temperatures, Paleoceanography, 9(2), 353387.
Zachos, J., M. Pagani, L. Sloan, E. Thomas, K. Billups, J. Smith, and J. Uppenbrink (2001), Trends, rhythms, and aberrations in global climate 65 Ma to present, Science, 292, 686-693.

E. Ledoux and R. Simon-Coinçon, Ecole Nationale Supérieure des Mines de Paris, UMR 7619 Sisyphe, 35, rue Saint Honoré, 77305, Fontainebleau Cedex, France.

J.-L. Michelot, Orsay Terre, FRE 2566 CNRS, Faculté des Sciences, Université de Paris-Sud, Bât. 504, 91405 Orsay Cedex, France.

D. Patriarche, Department of Geological Sciences, University of Michigan, 2534 C. C. Little Building, Ann Arbor, MI 48109-1063, USA (delfpat@umich.edu)

S. Savoye, Institut de Radioprotection et de Sûreté Nucléaire, BP 17, 92262 Fontenay-aux-Roses Cedex, France. 